\title{
Intensive Reading and Necessity to Integrate Learning Strategies Instruction
}

\author{
Weidong Yang (Corresponding author) \\ Foreign Languages Department, China University of Petroleum (Beijing) \\ 18 Fuxue Road, Changping District, Beijing 102249, China \\ Tel: 86-10-8973-3282Ｅ-mail: clarkdream@sina.com \\ Weiping Dai \\ Foreign Languages Department, China University of Petroleum (Beijing) \\ 18 Fuxue Road, Changping District, Beijing 102249, China \\ Tel: 86-10-8973-3282 E-mail: dwping@cup.edu.cn \\ Lijia Gao \\ Foreign Languages School, Jilin University \\ 2699 Qianjin Road, Chaoyang District, Changchun 300012, China \\ E-mail: tianping@jlu.edu.cn
}

$\begin{array}{ll}\text { Received: October 10, } 2011 & \text { Accepted: December 2, 2011 } \\ \text { doi:10.5539/ells.v2n1p112 } & \text { URL: http://dx.doi.org/10.5539/ells.v2n1p112 }\end{array}$

\begin{abstract}
For years great emphasis has been placed on Intensive Reading (IR) course. IR has dominated English language curriculum in the teacher-dominated class, students do nothing but just read, listen, write, translate, imitate, memorize. IR has incurred criticisms which point out disadvantages stemming from IR approach. A number of learning strategies, presumably relevant to IR course in Chinese context, are suggested for Chinese teachers of English. They may integrate instruction on the use of the suggested learning strategies with regular classroom activities.
\end{abstract}

Keywords: Intensive Reading, Criticism, Learning strategy

\section{Intensive Reading in Chinese Context}

Intensive Reading (IR) is a hair-splitting analysis of vocabulary and sentence structures, which dominates the ELT course throughout the three stages (elementary, secondary, and tertiary) of learning in China. Its dominance manifests itself in both contact class hours it takes (2/3 of the total) as well as the time and effort it draws from teachers and student alike. This domination has been enhanced by the introduction of Teachers' Books, of which the dominating feature is the detailed explanation of the text. This gives learners a false impression as if the only way to learn English were by analyzing the languages in a hair-splitting manner (Shu, 2010).

The term Intensive Reading per se may seem to be misleading to the ELT world outside China; it is not an intensive course in its usual sense such as a summer course which is relatively short with emphasis on reinforcement and high frequency of lessons.

Intensive Reading course at tertiary level in China drags on for four semesters (two semesters a year) for non-English-major students. IR is not a reading course designed to improve reading comprehension and speed, but is the core course in ELT which covers such contents as pronunciation, spelling, grammar, vocabulary, reading, composition, and translation and it is taught through a textbook.

In IR course teacher goes through each text in a linear fashion, word by word, and sentence by sentence in order that students may understand everything about the text in terms of grammatical structure, usage, vocabulary, and sentence understanding. IR class relies heavily on strong teacher control and apportions a major part of total talking 
to the teacher. The text is removed from its total context of meaning and examined as an object for analysis. Emphasis is placed on the rote memorization chosen from text. Besides, a lot of words elicited from each lesson have to be committed to memory on the part of students.

People usually read for information, it is, therefore, important to teach the student to read faster and read extensively, so that he/she can enhance his/her feel for the target language and develop unconscious language habits thereby. But it is equally important for a Chinese student of English to make a conscious and intensive study of the language and its fundamentals so as to overcome the vast gulf between his/her own language and the target language. When a student is still in the dark about the fundamentals of the English language, to let him/her indulge in extensive reading without proper guidance is to leave him/her feeling about blindly in a maze without getting anywhere. Therefore, at the initial stage and intermediate stage a guided intensive course has proved indispensable to systematic learning of basic grammar, structure, phonetics, basic vocabulary and useful idiomatic expressions. It has proved essential, especially when it is combined with writing, speaking and even listening, thus becoming a comprehensive language course. At these two stages, IR did have proved effective in enabling the student of English to acquire a sound knowledge of the language, to develop his/her five basic skills, that is, listening, speaking, reading, writing, and translating, to develop correct methods of study and ultimately to cultivate a capacity to work on his/her own. On such a solid foundation, a magnificent edifice of language proficiency can rise to an important height.

However, the importance of laying a solid foundation in language learning should by no means be overemphasized when the student has passed through the primary and secondary stages and successfully entered the advanced stage of his/her language learning. There should be accordingly a shift of stress as the learner moves from initial stage through intermediate stage to the advanced stage of learning. So far as we know, at the stage of post-graduate teaching, most universities and colleges continue to give top priority to intensive reading at the expense of other practical courses. Graduate students have to devote more than half their time and efforts to intensive reading courses.

\section{Four Centers in IR Courses}

With regard to the scope and content IR covers, it is a multi-purpose comprehensive course in Chinese context featured by four-centredness.

\section{Teacher-centredness}

The teacher is an authority, an intellectual, and a model. Teacher is regarded as a source of knowledge.

2. Textbook-centredness.

Each lesson consists of a model text supplemented by exercises surrounding phonetics, grammar, vocabulary, composition, translation, and reading comprehension. In fact the text itself serves as the basis for oral English practice (pronunciation, dialogues, question, composition, and translation).

\section{Grammar-centredness}

Texts are syntactically concerned with sentence patterns, and grammar analysis of the structures. Grammar-translation approaches are commonplace and the teacher and textbook transmit this subject knowledge to students.

\section{Vocabulary-centredness}

Vocabulary is a focus of instruction. On average 50-60 new words appear in each new lesson (16-18 texts per semester). Science students (not English majors) at tertiary level are required by the National Foreign Language Syllabus and exam system to learn 4000 words in two years' formal language learning.

\section{Criticisms Leveled at IR Approach}

IR approaches characterized by a hair-splitting analysis of text, emphasis on mimicry-memorization drills, overdoing mechanical exercises, and spoon-feeding, have incurred criticisms since early 1980s by some leading ELT professionals and researchers.

An American professor, who has achieved outstanding results in teaching English at Beijing University stated in a lecture, "The greatest harm done to students of English in China is IR. IR is not reading at all; it is deciphering, analyzing. It teaches students not to read but use dictionaries and grammar books. It teaches very bad study habits, which are very hard to break. It does more harm than good." (Dai, 2009: 22)

Other criticisms can be summarized as follows:

1. "The habitual way of advanced IR teaching hardly focus on reading skills but, trying to cover everything, has to a 
large extent, failed to achieve its wishful desire. The translation method and lecturing method, often adopted in the advanced IR teaching, are rather ineffective and, in the final analysis, a way of cramming”.(Xiao,2004)

2. It encourages slow reading. Stop-and-go reading destroys the continuity_continuous thought pattern. "It is a bar to the comprehension of particular text. It takes a student so long to reach the meanings and connotations of each phrase that he often can not understand or appreciate the meaning and significance of the text as a whole" (Short, 1994). The student may have forgotten what the beginning is about by the time he has reached the end of a passage or a text. It has resulted in what a Chinese saying calls "failure to see the wood for trees". It is interesting to note that there are many students who even incorporate some intensive reading in their extensive reading, pausing after covering several sentences or paragraphs to go back and re-read a selected sentence or paragraph with great care.

3. "The IR approach tends to increase student dependency on the teacher and the dictionary" (ibid). It discourages students from reading in an adequate, enquiring, active, hypothesizing manner. It can not train the students to learn how to stand on their own "thinking feet" as much as possible.

4. It is a bar to processing lots of different texts "since the emphasis of IR is on intensiveness and since whatever is taught is supposed to be mastered, a great restriction is placed on the quantity of language materials to be taught. Even if they have mastered everything in the text, what they have learned is limited in quantity. This greatly restricts their ability to understand and use the language" (Yue, 2005).

\section{Master Teacher and Apprentice Student}

China cherishes its education tradition. China's Confucian education system (Confucius, one of the greatest thinkers in ancient China, who laid the philosophical foundation for education in China) emphasizes teaching by strict model. Teachers are expected to be the model for people to follow. Teaching is viewed in China as a "sacred" occupation. Throughout the country, teachers are respected and regarded as authorities in the classroom.

Teachers are believed to be the authoritative source of knowledge. They are, therefore, obliged to impart knowledge to their students. They are expected to provide background knowledge, elaborate the text, lecture on the subject they teach, and give answers to controversial questions. As an authority in the classroom, teacher tells students what he thinks they ought to learn.

Students, on the other hand, see themselves as apprentice: their study is strongly based on the imitation of the teacher as "master" or "model". From childhood they have got used to learning things from the teacher and expecting him to do his job of clearing up all the perplexities in addition to passing on information. Because a long term tradition in Chinese pedagogy requires students to commit large amounts of information and "text" to memory, they have to internalize knowledge through close attention and mimicry-memorization. Since students have got accustomed to spoon-deeding method, even at tertiary level they still "expect the teacher to structure the learning situation for them, telling them what to learn and how to learn".(Nunan,1996)

Educated by the traditional education system, the majority of students lack the initiative to seek their own learning strategies, as they believe that they can learn everything they want from the teacher. Another belief that restricts their range of learning strategies is that proficiency can be attained solely through such traditional means as grammar translation, and rote memorization.

\section{Importance of Learning Strategy Instruction}

There should not be an excessive focus on IR and a concomitant lack of emphasis on communicative activities and use of target language. The ultimate goal for our students is to be able to use the language they are learning for their own purpose, to express their own meanings, that is to create their own formulations to express their intentions. To a learner of advanced learning (many students at this stage have passed Band 4 Examination administered by National Education Ministry to Non-English major students nationwide), he or she is faced with a world of ideas. At this stage he or she needs something like a compass to guide him/her through this confusing world of ideas. Therefore we ought to train and prepare the students

1. to willingly practice the English of their own accord

2. to constantly attach importance to their own use of target language and to their performance

3. to have a positive attitude towards the language in question and to its speakers

4. to learn to infer and make guesses about language data and how language works

5. to involve themselves as real people in the activities they are asked to undertake both inside and outside the classroom and to be independent as learners

6. to learn more effectively in a continuing way 
7. to constantly search for meaning.

To this end

1. We should leave no stone unturned to create the best possible linguistic environment and teach students to listen more, speak more, read more, and write more in English.

2. We should teach students to independently do some intensive study of target language, examining choice samples of English writing and speech and work on grammar, vocabulary, and other language matters.

3. We should cut down IR to increase Extensive Reading, Guided Composition, Listening Versatility, and Spoken English. We should give serious thought to the study of language materials relating to the students' deferred and immediate purpose.

4. We should immerse the students in the use of target language and engage them in language activities actively rather than passively. We should lay emphasis on student initiative and interaction rather than on teacher-centered direction.

5. We should lay weight in instruction on developing good learning strategies.

Oxford (1989), from her longitudinal studies of foreign language students' use of language learning strategies, found that language teaching methods, as well as unspoken expectations permeating the instructional environment, often influence language learning strategy use. The longer students remained in a language program, the more they tended to prefer the language learning strategies subtly suggested by the program's instructional methods.

This is quite true for the Chinese students of English. Given the traditional teacher-centred teaching style, students are forced to develop strategies that allow them to cope with the methods imposed by the textbooks and the techniques applied by the teacher.

Studies in the area of cognitive psychology show that learning strategies can help learners to assimilate new information into their existing schemata, which then enrich it to more complex schemata (Slobin, 1971; Anderson, 1980; Carrel, 1984). This concept is especially important in foreign language learning as learners need to be able to continue to learn independently once the teacher's scaffolding is removed.

In order to help students become efficient and independent learners - able, eventually to manage their own learning, Chinese teachers need to equip students through instruction with appropriate learning strategies which will allow students to take more responsibility for their own learning by enhancing their autonomy, independence, and self-direction.

Rather than assuming that the students will develop appropriate learning strategies on their own, instruction on the use of learning strategies should become a part of language teaching process in foreign language classroom. The ESL training study, conducted be O'Malley \& Chamot (1990), demonstrated that learning strategies instruction can be effectively implemented in real classroom settings.

The findings reported by Hashim \& Sshil (1994) also suggest that it is very important to incorporate language learning strategies into language course in order to provide learners with greater opportunity to make language learning an autonomous process. The focus of learning strategies woven into regular teaching process should be on helping students to learn how to learn by equipping them with tools they can use on their own.

\section{Suggested Learning Strategies}

Based on the research findings reported by O'Malley \& Chamot (1990) on learning strategies, a number of learning strategies, presumably relevant to IR course in Chinese context, are suggested for Chinese teachers of English. They may integrate instruction on the use of these suggested learning strategies with regular classroom activities (Xue, 2011).

Meta-cognitive Strategies.

\section{Advance Organization}

Jones (1957) recommends that reader should not punctuate his reading with excursions to the dictionary; but suggests that he should read the whole text first. In this view students should be taught to overcome the habit of going directly to the dictionary as soon as they identify an unknown item, they should be encouraged to identify the main ideas and concepts of the text by skim-reading first.

\section{Selective Attention}

Teach students how to locate in advance key words, concepts, and linguistic points in a new text that are to be the focus of a forthcoming language task. 


\section{Self-monitoring}

Teach students to foster a habit of checking, verifying, or correcting their understanding of the ongoing language task.

4. Problem Identification

Assign students after class to identify the prior language task-related problems that hinder understanding and need resolution in the next classroom activities.

\section{Cognitive Strategies}

\section{Resourcing}

Rather than resorting to pocket English-Chinese dictionary and Chinese versions of the text, students should be taught to use the target language reference materials such as monolingual, bilingual dictionaries, encyclopedia, and related prior work.

\section{Grouping}

First teach students how to classify words, terminology, or concepts taught in the previous texts according to their attributes or meaning, then encourage students do the classifying for the new text on their own.

\section{Deduction/Induction}

Teacher elicits from students application of grammatical rules to identify the forms of unknown words of the text, which leads to guesses about the type of words it would be (e.g. verb, noun, etc.).

\section{Elaboration}

Elaboration refers to the mental process of relating new knowledge to existing information in long-term memory. It has also been described as a process of making meaningful connection between different parts of new textual information. In light of it, teacher may point out what students have already learned and suggest how they can use this linguistic or world knowledge to an intelligent inference about the meaning of an unknown item. In reading comprehension, for instance, teacher may encourage students' use of prior knowledge, both academic and real world to make decisions about probable meaning.

\section{Transfer}

Teach students to learn to use previously acquired linguistic knowledge or prior skills to facilitate the understanding or production of the present language task.

\section{Inferencing}

"Help student develop strategies and knowledge to use internal and external contexts to infer meaning is a major step towards helping them become independent learners." (Kang \& Golden, 1994). In this view teacher should teach students to learn how to use the internal context of words, such as root stems, affixes, to infer their meaning. In reading comprehension, teach students to use immediate and extended context to guess new words.

\section{Summarizing}

Teach students to learn to foster a healthy habit of summarizing the previously learned paragraph or text in their own words.

\section{Discussion and Conclusion}

Developed since the early 1950s, IR has been the dominant ELT course in most institutions of higher learning of China. Looking back in its historical perspective it was the product of a particular social, economic, and linguistic situation in China. Even at present exposure to English in the second and third-tier cities of China is still limited and the range of English-medium activities is very narrow. Original English teaching and learning related materials are relatively scarce in most libraries at tertiary level in the second and third-tier cities of China, and opportunity for interaction with native speakers even more so.

Given this situation it is predicted that with its comprehensive training and rich exercises, IR will continue to be an indispensable ELT course in China, despite its problems as in methodology and with textbooks.

In order to enable students to cultivate a capacity to be ultimately an autonomous reader and work independently Chinese teachers in IR course should go beyond their traditional role of knowledge provider. They need to weave learning strategies instruction into regular language task-related activities.

Class instruction on learning strategies can help students gain awareness of learning strategies. "The greater the strategy awareness of learners, the more likely they will be to use task-appropriate learning strategies that help them overcome their general learning style limitations, and the more likely that these strategies will assist in processing, 
retrieving, and using new language information" (Nyikos \& Oxford,1993).

In this view teachers in IR course should create circumstances in which students can be informed of and apply strategies that are appropriate for the type of language task-related activities being presented.

Further, teachers should encourage and help students apply the strategies to an expanded range of language activities and materials so that the strategies transfer to new activities and are used by students independently of the teachers' support (Hu, 2011).

\section{References}

Anderson, J. R. (1980). Cognitive Psychology and Its Implications. San Francisco: Freeman.

Carrell, P. (1984). Evidence of Formal Schema in Second Language Comprehension. Language Learning, 34, 87-112. http://dx.doi.org/10.1111/j.1467-1770.1984.tb01005.x

Dai, W. (2009). Some Thoughts On Intensive Reading at the Stage of Post-graduate Teaching. Teachers of Foreign Languages In Graduate Schools, 9(1), 21-25

Hashim, R. A., \& Sahil, S. A. (1994). Examining Learners' Language Learning Strategies. RELC Journal, 25(2), $1-20$

Hu, J. (2011). Evaluating Autonomous Foreign Language Learning Capacity. Journal of The Foreign Language World, No.4 (General Serial No. 145), 12-17

Jones, W. K. (1957). Cultivating Reading Speed in Spanish. Modern Language Journal, 15, 126. http://dx.doi.org/10.1111/j.1540-4781.1957.tb06646.x

Kang, H., \& Golden, A. (1994). Vocabulary Learning and Instruction in a Second or Foreign Language. International Journal of Applied Linguistics, 4(1), 57

Nunan, D. (1996). Learner Strategy Training in the Classroom: an Action Research Study. TESOL Journal, 6( 1), 35

Nyikos, M., \& Oxford, R. (1993). A Factor Analytic Study of Language Learning Strategy Use: Interpretations from Information-Processing Theory and Social Psychology. Modern Language Journal, 77, 13. http://dx.doi.org/10.1111/j.1540-4781.1993.tb01940.x

O'Malley, J. M., \& Chamot, A. U. (1990). Learning Strategies in Second Language Acquisition. Cambridge University Press.

Oxford, R. (1989). Use of Language Learning Strategies: a Synthesis of Studies with Implications for Strategy Training. System, 17(2), 235-247

Short, M. H. (1994). What I Know about Reading and What Little I Know about Intensive Reading. Foreign Language Teaching and Research, 58(2), 49-56

Shu, D. (2010). Reflection on the Contents and Methods of CET Classroom Teaching. Journal of The Foreign Language World, No.6 (General Serial No. 141), 26-32

Slobin, D. I. (1971). Developmental Psycholinguistics. In Dingwall. W. O. (ed.), A Survey of Linguistic Science. College Park, Md: University, Maryland Linguistic Program.

Xiao, J. (2004). Some Thoughts on the Teaching of Intensive Reading at Advanced Level. Foreign Language Teaching and Research, 58(4), 37

Xue, J. (2011). Interaction Between L2 Proficiency and Metacognitive Experience in Reading Training. Journal of The Foreign Language World, No.2 (General Serial No. 143), 50-56

Yue, M. (2005). A Skill-Based Approach to Freshman English-an Experimental Report. Papers Presented at the International Symposium on Teaching English in the Chinese Context, Guangzhou, China. Foreign Language Teaching and Research Press, Beijing, China.

\section{Bio Data}

Yang Weidong, male, born in 1972, lecturer of English with the Department of Foreign Languages, China University of Petroleum. Specialize in English Language Teaching. Over 20 papers and books published.

Dai Weiping, male, born in 1956, professor of English with the Department of Foreign Languages, China University of Petroleum. Attained M.A. in ELT from Essex University, UK in 1996. Specialize in English Language Teaching. Over 100 papers and books published.

Gao Lijia, female, born in 1960, professor of English with the School of Foreign Languages, Jilin University. Attained M.A. in English Literature from Jilin University in 1999. Specialize in English Language Teaching. Over 30 papers and books published. 